\title{
First Evidence on Heterotic Affinity and Combining Ability of Cultivated Okra [Abelmoschus esculentus (L.) Moench] Inbred Lines for Tolerance to Enation Leaf Curl Virus Disease
}

\author{
Yogendra Yadav1, Praveen Kumar Maurya ${ }^{1}$, Tridip Bhattacharjee ${ }^{1}$, Swadesh Banerjee ${ }^{1}$, Imtinungsang Jamir ${ }^{2}$, \\ Asit Kumar Mandal' ${ }^{2}$, Subrata Dutta ${ }^{2}$ and Arup Chattopadhyay ${ }^{1 *}$
}

${ }^{1}$ Faculty of Horticulture, Bidhan Chandra Krishi Viswavidyalaya, India

${ }^{2}$ Faculty of Agriculture, Bidhan Chandra Krishi Viswavidyalaya, India

Submission: November 11, 2018, Published: November 29, 2018

"Corresponding author: Arup Chattopadhyay, Faculty of Horticulture, Department of Vegetable Science, Bidhan Chandra Krishi Viswavidyalaya, Mohanpur, Nadia, West Bengal, India

\begin{abstract}
Among the viral diseases, enation leaf curl virus (ELCV) has now becoming a menace in okra cultivation particularly in the tropics. Okra parents and hybrids tolerant to ELCV disease were selected based on estimates of combining ability and heterobeltiosis in the Gangetic plains of West Bengal, the most productive okra growing zones in eastern India. Eight diverse lines were crossed in diallel fashion without reciprocals to obtain $28 \mathrm{~F}_{1}$ s. Additive genetic control of ELCV disease severity suggested use of pure line selection in the advanced generations from the highly heterotic crosses could be the best possible method to improvement of this trait. Two parents 285-1-3A-1-17-1 and VRO-178 with good general combining ability effects for tolerance to ELCV disease can now be used in future breeding programme. Partial- to over-dominance reactions for the inheritance of studied traits were recorded. We could able to isolate two outstanding hybrids 285-1-5-1-16-23 $\times$ VRO-178 and 285-13-1-15-2-1 $\times$ VRO-178 based on fruit yield and ELCV disease tolerance under field and epiphytotic conditions, and they could be commercially exploited after critical evaluations. Our study also suggests that either the identified donor parents will be used to develop backcross populations or exploiting promising hybrids in segregating populations for generating new inbred lines with much higher levels of tolerance to ELCV disease in okra.
\end{abstract}

Keywords: Combining ability; Dominance effect; ELCV; Heterobeltiosis; Okra

Abrreviations: ELCV: Enation Leaf Curl Virus; YVMV: Yellow Vein Mosaic Virus; DAS: Days After Sowing; PDI: Percent Disease Index; GCA: General Combining Ability; SCA: Specific Combining Ability; DE: Dominance Effect

\section{Introduction}

Okra [Abelmoschus esculentus (L.) Moench] is a sexually propagated hot weather crop sensitive to frost, low temperature, water-logging as well as drought conditions [1]. Okra is considered as an important constituent for balanced food due to its dietary fibers and amino-acid composition rich in lysine and tryptophan [2]. The process of development of hybrids in okra is not different from other vegetable crops, viz., development of in breds, testing of combining ability and production of $F_{1}$ hybrid seeds. Here, breeding lines/cultigens/varieties stable for phenotypic characters can be taken as parents to study combining ability and develop hybrids. Several biotic [yellow vein mosaic virus (YVMV), enation leaf curl virus (ELCV), fruit and shoot borer, wilt, powdery mildew] and abiotic (soil salinity) challenges limit okra production considerably in certain areas. Incorporation of resistance or tolerance to one or more of these in the $F_{1}$ hybrid is possible and will help in realizing sustainable yield even under problematic environment.

Okra production in the Gangetic plains of eastern India is threatened over the years due to high incidence of YVMV disease [3]. Now-a-days, ELCV is one of the emerging diseases of okra in eastern parts of India, particularly in West Bengal [4]. The first report of the association of an alpha satellite with ELCV from India was cited by Chandran et al. [5]. The natural transmission of the disease occurs through whitefly [6]. In our previous study we observed that okra plants either expressed YVMV or ELCV symptoms, but not both, in a population [7]. The important symptoms of this disease are curling of leaves in an adaxial direction, and mild or bold enations on the under surface of the leaves which become thick and deformed. The other characteristic symptoms are twisting of the main stem, lateral branches and leaf 
petiole. In case of heavy infection, the plant growth is retarded Fruits from infected plants are small and deformed and unfit for marketing. Under favourable condition, $100 \%$ loss in yield can be found [8]. Lack of sources of resistance to this virus in cultivated species has forced breeders to look into the wild species for resistance sources [9]. However, the transfer of resistance from wild relatives has also been hampered by sterility problems [10]. Hence continuous search for new sources of resistance among the cultivated species and development of better hybrids/varieties with higher level of ELCV disease tolerance would be the prime objective.

The proper choice of parents is a prerequisite in any sound breeding programme. Genetic diversity as well as the combining ability is considered as the most important criteria for the selection of parents in the production of a hybrid [11]. Combining ability is an effective tool for generating useful basic genetic information for the choice of parents and their performance in a series of crosses [12]. Such studies also simultaneously illustrate the nature and magnitude of gene action involved in the expression of desirable traits. Okra offers much scope of improvement through heterosis breeding $[13,14]$, which can further be utilized for the development of desirable recombinants. Diallel [15], is a useful technique for preliminary evaluation of genetic stock for use in hybridization programme with a view to identify good general- as well as specific-combiners. The mode of inheritance of resistance to ELCV disease in okra is still unclear among the researchers. The genetic background and environment play a large part in determining the mode of inheritance of resistance to ELCV disease, and this information is needed for the development of resistant hybrids in okra. Therefore, the main objective of the present investigation was to assess the extent of heterobeltiosis in desired direction and to estimate the dominance reaction for yield and its components, and ELCV disease severity, and to determine the nature of gene action for studied traits with a view to identify good combiners, as well as to frame the breeding strategy for the genetic improvement of such characters.

Table 1: Disease rating scale of ELCV disease.

\section{Materials and Methods}

Eight diverse genotypes 285-1-3A-1-17-1, VRO-104, 285-1-51-16-23, 285-1-3-1-15-2-1, VRO-178, 299-52-5-6-5-8, BCO-1, and VRO-106 including tolerant and susceptible to ELCV disease were selected on the basis of multivariate analysis [7], to raise 28 cross combinations following diallel mating design without reciprocals during spring- summer (February to May) season of 2015.

Seeds of $28 \mathrm{~F}_{1} \mathrm{~s}$ and 8 parental lines were sown in the third week of July, 2015 when the activity of whitefly and incidence of viral diseases reaches its peak in a Randomized Block Design with three replications at Bidhan Chandra Krishi Viswavidyalaya, Kalyani, Nadia, West Bengal, India under the research field of All India Coordinated Research project on Vegetable Crops. Plot size of $3.0 \mathrm{~m}$ length and $2.7 \mathrm{~m}$ width was allotted to each genotype. Spacing between rows was $60 \mathrm{~cm}$ and plants within the rows were spaced by $30 \mathrm{~cm}$ accommodating 45 plants in each plot for each genotype. Normal package of practices was followed to raise the good crop [16]. Observations were recorded on different characters like days to $1^{\text {st }}$ flowering, days to $50 \%$ flowering, node number at $1^{\text {st }}$ flowering, plant height $(\mathrm{cm})$, number of primary branches/plant, fruit length $(\mathrm{cm})$, fruit diameter $(\mathrm{cm})$, fruit weight (g), number of fruits/plant, days to $1^{\text {st }}$ initiation of ELCV disease, node at $1^{\text {st }}$ initiation of ELCV disease, PDI of ELCV(\%) and fruit yield per plant (g). Fruits of harvestable maturity (7 days after anthesis) were taken to record different fruit characters.

All the hybrids and parental lines were grown without any protective cover of systemic insecticides to take data on percent disease index (PDI\%) of ELCV. PDIs (\%) in the genotype were recorded replication wise at five stages at an interval of 15 days starting from 30 days after sowing (DAS) up to 90 DAS. Cupping of leaves and petiole bending of any form in the plant were treated as ELCV disease incidence. The PDI of ELCV was expressed as percentage from all 54 plants in a replication using following disease severity scale as suggested by Alegbejo [17] (Table 1).

\begin{tabular}{|c|c|}
\hline Scale & Description of symptom \\
\hline 1 & Top leaves curled \\
\hline 3 & Top leaves curled and slight stunting of plant \\
\hline 5 & All leaves curled, twisting of petiole and slight stunting of plant \\
\hline 7 & Severe curling of leaves, twisting of petiole, stunting of plant and proliferation of auxiliary branches \\
\hline
\end{tabular}

Number of plants infected in each entry was recorded and PDI of ELCV was calculated with the following formula:

$$
P D I=\frac{\text { Numerical ratings }}{\text { Highest grade of rating } \times \text { total number of plants of the entry examined }} \times 100
$$

Tolerance to ELCV was confirmed by feeding of viruliferous whitefly as suggested by Nariani and Seth [18], in related species of okra. Artificial inoculation by viruliferous whitefly for screening of virus free germplasm and confirmation of presence and/ or absence of the virus was done under poly house condition. A wooden frame measuring $45 \times 45 \times 30 \mathrm{~cm}$ was fixed with glass and muslin cloth and the frame was fit on a wooden rectangular base of $45.5 \times 45.5 \times 10 \mathrm{~cm}$. Forty whiteflies were released on twenty okra plants of two most field tolerant hybrids and one most susceptible hybrid grown inside the insect proof rearing cages and subsequently maintained by introducing the young plants into rearing cage. Whiteflies were collected from ELCV infected plants by sucking with the help of the aspirator by slowly turning the leaves slightly upwards. Whiteflies were starved for 1-2 hours and then they were subjected to artificial inoculation feeding for 4-5 hours using ELCV infected leaves. After the acquisition period, two 
viruliferous whiteflies per plant were released on the seedlings inside the cages as suggested by Venkataravanappa et al. [6], for the infection of the disease and the feeding of vector on the plants was ensured since they were protecting inside the cages.

Combining ability analysis was carried out according to Singh and Chaudhary [19], based on Griffing's [15], fixed effect model using the following formula:

$$
Y_{i j}=m+g_{i}+g_{j}+s_{i j}+r_{i j}+1 / b c \Sigma \sum_{i j k l}
$$

Where $\mathrm{i}, \mathrm{j}=1,2 \ldots \ldots . . \mathrm{n} ; \mathrm{k}=1,2, \ldots \ldots . \mathrm{b} . \mathrm{l}=1,2, \ldots \ldots \ldots \ldots . . \mathrm{c} ; \mathrm{Y}_{\mathrm{ij}}$ is the mean of $\mathrm{i} \times \mathrm{j}$ genotype over $\mathrm{k}$ and $\mathrm{l} ; \mathrm{m}$ is the population mean; $\mathrm{g}_{\mathrm{i}}$ is the GCA effect of the $i^{\text {th }}$ parent; $g_{j}$ is the GCA effect of the $j^{\text {th }}$ parent; $\mathrm{S}_{\mathrm{ij}}$ is the SCA effect; $\mathrm{r}_{\mathrm{ij}}$ is the reciprocal effect; and $1 / \mathrm{bcSS}_{\mathrm{ijkl}}$ is the mean error effect.

Heterosis over better-parent (Heterobeltiosis) was estimated in terms of per cent increase or decrease of the $\mathrm{F}_{1}$ hybrid over its better-parent as per Hayes et al. [20]. Potence ratio often referred to as "dominance effect" (D.E.) was computed using the method of Smith [21]. The analysis was computed by using computer software programme INDOSTAT 8.1 (developed by Indostat services, Ameerpet, Hyderabad, India).

\section{Results and Discussion}

Analysis of variance for parents and hybrids was presented (Table 2). The parents were highly significant for all the characters under study. Among the highly significant parental differences, differences among both parents and hybrids were very high excepting fruit diameter. These highly divergent parental lines indicated their suitability for developing divergent hybrids. Parents vs. hybrids variance was also significant for node at $1^{\text {st }}$ flowering, plant height, node at $1^{\text {st }}$ initiation of ELCV disease, PDI of ELCV and fruit yield/plant, indicated that average heterosis was also highly significant for such traits. Thus, considerable amount of average heterosis was reflected in the hybrids. Significant differences among the hybrids for all the characters except fruit diameter meant varying performance of the cross combinations for all the characters except fruit diameter.

Table 2: Analysis of variance (mean squares) for 13 characters in $8 \times 8$ half diallel cross of okra.

\begin{tabular}{|c|c|c|c|c|c|c|c|c|c|c|c|c|c|}
\hline $\begin{array}{c}\text { Source of } \\
\text { Variation (df) }\end{array}$ & $\begin{array}{l}\text { Days } \\
\text { to } 1^{\text {st }} \\
\text { Flow- } \\
\text { ering }\end{array}$ & $\begin{array}{c}\text { Days } \\
\text { to } 50 \% \\
\text { Flower- } \\
\text { ing }\end{array}$ & $\begin{array}{l}\text { Node at } \\
1^{\text {st }} \text { Flow- } \\
\text { ering }\end{array}$ & $\begin{array}{c}\text { Plant } \\
\text { Height } \\
\text { (cm) }\end{array}$ & $\begin{array}{l}\text { Primary } \\
\text { Branch- } \\
\text { es/ } \\
\text { plant }\end{array}$ & $\begin{array}{l}\text { Fruit } \\
\text { Length } \\
\text { (cm) }\end{array}$ & $\begin{array}{l}\text { Fruit } \\
\text { Diam- } \\
\text { eter } \\
(\mathrm{cm})\end{array}$ & $\begin{array}{c}\text { Num- } \\
\text { ber of } \\
\text { Fruits/ } \\
\text { Plants }\end{array}$ & $\begin{array}{l}\text { Fruit } \\
\text { Weight } \\
\text { (g) }\end{array}$ & $\begin{array}{l}\text { Days to } \\
1^{\text {st }} \text { Initi- } \\
\text { ation of } \\
\text { ELCV }\end{array}$ & $\begin{array}{l}\text { Node at } 1^{\text {st }} \\
\text { Initiation } \\
\text { of ELCV }\end{array}$ & $\begin{array}{c}\text { PDI of } \\
\text { ELCV at } \\
90 \text { DAS } \\
(\%)\end{array}$ & $\begin{array}{c}\text { Fruit } \\
\text { Yield/ } \\
\text { Plant (g) }\end{array}$ \\
\hline Replication (2) & 0.35 & 1.04 & 0.01 & 0.46 & 0.01 & 0.01 & 0.01 & 0.28 & 0.22 & 0.06 & 0.15 & 0.4 & 0.43 \\
\hline $\begin{array}{l}\text { Treatments } \\
\text { (35) }\end{array}$ & $37.15^{* *}$ & $26.84^{* *}$ & $7.16^{* *}$ & $619.77^{* *}$ & $1.66^{* *}$ & $3.84^{* *}$ & $0.03^{*}$ & $35.81^{* *}$ & $9.74^{* *}$ & $94.33^{* *}$ & $9.68^{* *}$ & $533.39 * *$ & $5657.02^{* *}$ \\
\hline Parents (7) & $44.95^{* *}$ & $30.38^{* *}$ & $12.57^{* *}$ & $782.68^{* *}$ & $0.74^{* *}$ & $3.18^{* *}$ & $0.04^{*}$ & $17.95^{* *}$ & $17.66^{* *}$ & $91.90^{* *}$ & $11.95^{* *}$ & $591.59^{* *}$ & $1763.40^{* *}$ \\
\hline Hybrids (27) & $35.97^{* *}$ & $26.73^{* *}$ & $5.40^{* *}$ & $592.86^{* *}$ & $1.96^{* *}$ & $4.14^{* *}$ & 0.03 & $38.60^{* *}$ & $7.95^{* *}$ & $98.39^{* *}$ & $9.27^{* *}$ & $533.25^{* *}$ & $6429.88^{* *}$ \\
\hline $\begin{array}{l}\text { Parents vs. } \\
\text { Hybrids (1) }\end{array}$ & 14.69 & 5.24 & $16.70^{* *}$ & $205.85^{*}$ & 0.04 & 0.25 & 0.04 & $85.45^{* *}$ & $2.50^{* *}$ & 1.93 & $5.01^{* *}$ & $129.77^{* *}$ & $12045.08^{* *}$ \\
\hline Error (70) & 4.13 & 3.93 & 1.16 & 40.21 & 0.07 & 0.07 & 0.02 & 0.24 & 0.08 & 2.15 & 0.18 & 1.01 & 18.3 \\
\hline
\end{tabular}

* and **: significant at $P<0.05$ and $P<0.01$, respectively.

Table 3: Analysis of variance (mean squares) for combining ability (Griffing's Model 1 and Method 2) of 13 characters of okra.

\begin{tabular}{|c|c|c|c|c|c|c|c|c|c|c|c|c|c|}
\hline $\begin{array}{c}\text { Source of } \\
\text { Variation (df) }\end{array}$ & $\begin{array}{l}\text { Days to } \\
1^{\text {st }} \text { Flow- } \\
\text { ering }\end{array}$ & $\begin{array}{c}\text { Days } \\
\text { to } 50 \% \\
\text { Flowering }\end{array}$ & $\begin{array}{l}\text { Node } \\
\text { at } 1^{\text {st }} \\
\text { Flow- } \\
\text { ering }\end{array}$ & $\begin{array}{l}\text { Plant } \\
\text { Height } \\
\text { (cm) }\end{array}$ & $\begin{array}{c}\text { Number of } \\
\text { primary } \\
\text { branches/ } \\
\text { Plant }\end{array}$ & $\begin{array}{l}\text { Fruit } \\
\text { Length } \\
\text { (cm) }\end{array}$ & $\begin{array}{l}\text { Fruit } \\
\text { Diam- } \\
\text { eter } \\
\text { (cm) }\end{array}$ & $\begin{array}{c}\text { Num- } \\
\text { ber of } \\
\text { Fruits/ } \\
\text { Plant }\end{array}$ & $\begin{array}{c}\text { Fruit } \\
\text { Weight } \\
\text { (g) }\end{array}$ & $\begin{array}{l}\text { Days to } \\
1^{\text {st }} \text { Initi- } \\
\text { ation of } \\
\text { ELCV }\end{array}$ & $\begin{array}{l}\text { Node at } \\
1^{\text {st }} \text { Initi- } \\
\text { ation of } \\
\text { ELCV }\end{array}$ & $\begin{array}{c}\text { PDI of } \\
\text { ELCV at } \\
90 \text { DAS } \\
(\%)\end{array}$ & $\begin{array}{c}\text { Fruit } \\
\text { Yield/ } \\
\text { Plant (g) }\end{array}$ \\
\hline GCA (7) & $29.29^{* *}$ & $6.62^{* *}$ & $2.07^{* *}$ & $445.46^{* *}$ & $1.33^{* *}$ & $1.51^{* *}$ & $0.02^{* *}$ & $34.85^{* *}$ & $7.76^{* *}$ & $110.66^{* *}$ & $13.05^{* *}$ & $748.55^{* *}$ & $6174.96^{* *}$ \\
\hline SCA (28) & $8.16^{* *}$ & $9.53^{* *}$ & $2.46^{* *}$ & $146.87^{* *}$ & $0.36^{* *}$ & $1.22^{* *}$ & 0.01 & $6.21^{* *}$ & $2.12^{* *}$ & $11.64^{* *}$ & $0.77^{* *}$ & $35.11^{* *}$ & $813.35^{* *}$ \\
\hline Error (70) & 1.38 & 1.31 & 0.39 & 13.4 & 0.02 & 0.02 & 0.01 & 0.08 & 0.03 & 0.72 & 0.06 & 0.34 & 6.1 \\
\hline$\alpha^{2} a$ & 5.58 & 1.06 & 0.34 & 86.41 & 0.26 & 0.3 & 0 & 6.95 & 1.55 & 21.99 & 2.6 & 149.64 & 1233.77 \\
\hline$\alpha^{2}$ na & 6.78 & 8.22 & 2.08 & 133.47 & 0.34 & 1.2 & 0 & 6.13 & 2.09 & 10.92 & 0.71 & 34.77 & 807.25 \\
\hline$\frac{\alpha^{2} a}{\alpha^{2} a+\alpha^{2} n a}$ & 0.45 & 0.11 & 0.14 & 0.39 & 0.44 & 0.2 & 0.54 & 0.53 & 0.43 & 0.67 & 0.78 & 0.81 & 0.6 \\
\hline
\end{tabular}

**: significant at $\mathrm{P}<0.01 \%$.

The analysis of variance for combining ability based on Griffing's Model 1 and Method 2 illustrated that components of GCA and SCA mean squares were highly significant for fruit yield/ plant along with other quantitative traits in $\mathrm{F}_{1}$ generation except fruit diameter where SCA mean square was non-significant (Table
3). This indicated that the inheritance of fruit yield/plant, most of the yield components and ELCV disease severity traits were apparently controlled by both additive and non-additive gene action as their GCA variances being higher than their respective SCA variances. 
A general trend of the genetic control of the character can be ascertained from the estimates of additive and non-additive variance components. The relative importance of additive and non-additive genetic effects for the character was reflected by the predictability ratio as per Becker [22]. Predictability ratio close to unity (more than 0.8 ) indicates predominance of additive gene effect, ratio varies between $\geq 0.5$ and $<0.8$ indicates both additive and non-additive gene effect, and ratio $<0.5$ indicated non-additive gene effect for the particular trait. The present study reflected the preponderance of non-additive gene effects for days to $1^{\text {st }}$ flowering, days to $50 \%$ flowering, node at $1^{\text {st }}$ flowering, plant height, number of primary branches/plants, fruit length, and fruit weight (Table 3). On the other hand, fruit diameter, number of fruits/plants days to $1^{\text {st }}$ initiation of ELCV disease, node at $1^{\text {st }}$ initiation of ELCV disease and fruit yield/plant were controlled by both additive and non-additive gene action. In contrast, predictability ratio was higher than 0.80 for PDI of ELCV indicating additive genetic control for the conditioning of this trait (Table 3).

The importance of non-additive gene action for the conditioning of most of the yield components in the present study indicates heterosis breeding to be the best possible option for improving these traits in okra. While a population improvement approach in the form of diallel selective mating [23], or mass selection with concurrent random mating [24], or restricted recurrent selection by intermating the most desirable segregants followed by selection [25], could be followed for the exploitation of both additive and non-additive gene action for fruit diameter, number of fruits/plant, days to 1st initiation of ELCV disease, node at 1st initiation of ELCV disease and fruit yield/plant. Due to the predominance of additive gene action in PDI of ELCV inheritance, selection of such trait should be done in later generation when the effects of non-additive gene action will be minimized and those of additive gene action effects will be fixed. The response of additive gene action for the conditioning of PDI of ELCV was not so far been reported. The preponderance of both additive and non-additive gene action for the control of fruit diameter and fruit yield/plant [26], and number of fruits/plants [27], was also noted. The overwhelming response of non-additive gene action for days to $1^{\text {st }}$ flowering, days to $50 \%$ flowering, node at $1^{\text {st }}$ flowering, plant height, number of branches/plants, fruit length, and number of fruits/plants [14], was documented. In contrast to the present findings, non-additive genetic control of fruit weight was observed by Das et al. [13]. Such disparities in the previous reports in estimation of gene action controlling different characters may arise from differences in the genetic constitution of the parental materials, variation in the environment, the mating designs and the precision of the experiment.

The diallel analysis helps to identify the most promising combining parents and crosses for the different quantitative traits under study in addition to provide estimates of combining ability variances for the characters to be improved. The GCA effects of the parents used in the present study for thirteen quantitative traits are given in Table 4. It appeared that the parents differ in their GCA effects for all the characters under study. No single parent was found to be a good combiner for all the traits under study. The maximum significant gca effects in desired directions were recorded by VRO-178 for eight characters namely, fruit yield/plant followed by PDI of ELCV disease, days to $1^{\text {st }}$ initiation of ELCV disease, node at $1^{\text {st }}$ initiation of ELCV disease, fruit weight, number of fruits/plants, fruit length, number of primary branches/plants, days to $1^{\text {st }}$ flowering, and days to $50 \%$ flowering. Next to VRO-178, significant GCA effects in desired direction for fruit yield/plant, PDI of ELCV, days to $1^{\text {st }}$ initiation of ELCV disease, node at $1^{\text {st }}$ initiation of ELCV disease and number of fruits/ plants were shown by 285-1-3A-1-17-1. Consequently, 285-1-3-1-15-2-1 exhibited significant and desired GCA effects for fruit yield/plant followed by PDI of ELCV, days to $1^{\text {st }}$ initiation of ELCV disease, fruit weight and fruit diameter. However, 299-52-5-6-5-8 also exhibited positive significant GCA effects for fruit yield/plant and other desirable traits but their magnitude was low.

Table 4: Estimates of general combining ability (gi) effects and per se performances in 8 parents over $28 \mathrm{~F} 1 \mathrm{~s}$ of okra.

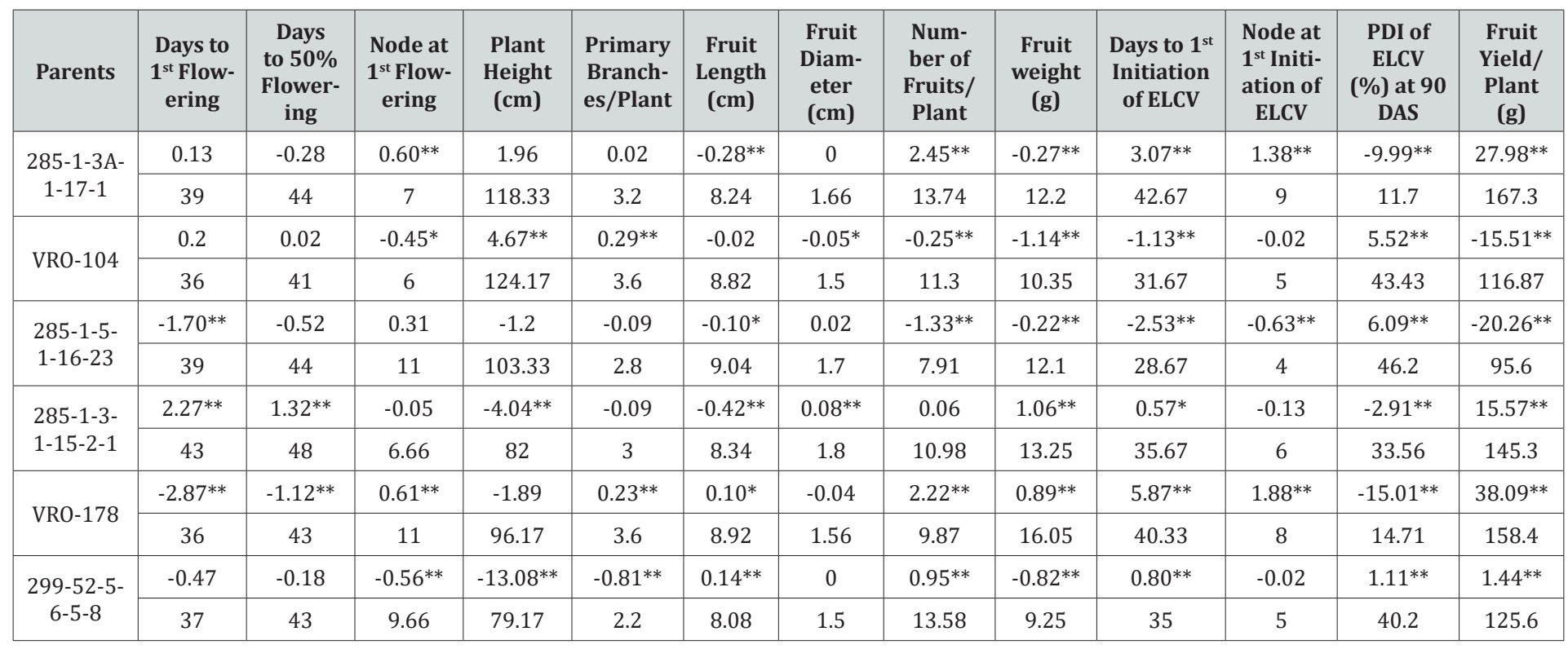




\section{Agricultural Research \& Technology: Open Access Journal}

\begin{tabular}{|c|c|c|c|c|c|c|c|c|c|c|c|c|c|}
\hline \multirow{2}{*}{ BCO-1 } & 0.5 & -0.32 & -0.2 & $7.70^{* *}$ & $0.13^{* *}$ & $0.84^{* *}$ & 0.04 & $-3.12^{* *}$ & $1.05^{* *}$ & $-4.53^{* *}$ & $-1.63^{* *}$ & $9.34^{* *}$ & $-29.72^{* *}$ \\
\cline { 2 - 44 } & 42 & 45 & 7 & 111.17 & 3.6 & 1086 & 1.7 & 7.19 & 15.95 & 26.33 & 3 & 47 & 114.6 \\
\hline \multirow{2}{*}{ VRO-106 } & $1.93^{* *}$ & $1.08^{* *}$ & -0.25 & $5.88^{* *}$ & $0.31^{* *}$ & $-0.25^{* *}$ & -0.03 & $-0.98^{* *}$ & $-0.56^{* *}$ & $-2.10^{* *}$ & $-0.82^{* *}$ & $5.86^{* *}$ & $-17.60^{* *}$ \\
\cline { 2 - 18 } & 47 & 51 & 7 & 96.5 & 3.4 & 10.46 & 1.78 & 8.77 & 13.85 & 32.33 & 5 & 42.5 & 121.42 \\
\hline \multirow{2}{*}{ SE(gi) } & 0.82 & 0.8 & 0.44 & 2.56 & 0.11 & 0.1 & 0.05 & 0.2 & 0.11 & 0.59 & 0.17 & 0.41 & 1.73 \\
\hline
\end{tabular}

* and **: significant at $\mathrm{P}<0.05$ and $\mathrm{P}<0.01$, respectively; Figures in bold letters indicate per se (mean) performance.

The highest per se performance for fruit yield/plant along with number of fruits/plants, and minimum severity of ELCV disease was recorded in 285-1-3A-1-17-1 followed by VRO-178 (Table 4). Thus, two parental lines 285-1-3A-1-17-1 and VRO-178 were found most promising because they produced the maximum frequency of high yielding hybrids with appreciable ELCV disease tolerance when crossed with other parents. These two parents

could be identified as good general combiners for future use in breeding programme of okra. Significant and positive GCA effects for fruit yield/ plant and number of fruits/plants [13,14], fruit length, fruit diameter and fruit weight [27], were also reported. While, negatively significant GCA effects for days to $1^{\text {st }}$ flowering $[13,14]$, days to $50 \%$ flowering and node at $1^{\text {st }}$ flowering [14], were also recorded.

Table 5: Estimates of heterobeltiosis, SCA effects and type of cross combinations for 10 characters in hybrids.

\begin{tabular}{|c|c|c|c|c|c|}
\hline Characters & $\begin{array}{l}\text { Better Crosses in De- } \\
\text { sirable Direction }\end{array}$ & $\begin{array}{l}\text { Significant Hetero- } \\
\text { beltiosis }(\%)\end{array}$ & $\begin{array}{l}\text { Range of Hetero- } \\
\text { beltiosis (\%) }\end{array}$ & $\begin{array}{l}\text { Crosses having sca Effects } \\
\text { with per se Performance }\end{array}$ & $\begin{array}{l}\text { Type of Combina- } \\
\text { tions }\end{array}$ \\
\hline $\begin{array}{l}\text { Days to } 50 \% \text { Flow- } \\
\text { ering }\end{array}$ & $\begin{array}{c}285-1-3-1-15-2-1 \times \\
\text { VRO-178 }\end{array}$ & $-9.30^{*}$ & 23.26 to -9.30 & $-5.66^{* *}(39.00)^{\mathrm{a}}$ & $\mathrm{L} \times \mathrm{Hb}$ \\
\hline \multirow{2}{*}{ Node at $1^{\text {st }}$ Flowering } & $\begin{array}{c}285-1-5-1-16-23 \times 299- \\
52-5-6-5-8\end{array}$ & $-41.41^{* *}$ & 50.00 to -41.41 & -8.6598 & $\mathrm{~L} \times \mathrm{L}$ \\
\hline & $\begin{array}{c}285-1-5-1-16-23 \times \\
\text { VRO-178 }\end{array}$ & $-24.27^{* *}$ & & $-0.02(8.33)$ & $\mathrm{L} \times \mathrm{H}$ \\
\hline \multirow{2}{*}{ Plant Height (cm) } & BCO-1 × VRO-106 & $19.04^{* *}$ & -30.20 to 19.04 & $19.98^{* *}(132.33)$ & $\mathrm{L} \times \mathrm{H}$ \\
\hline & VRO-178 × VRO-106 & $13.78^{* *}$ & & $7.04 *(109.80)$ & $\mathrm{H} \times \mathrm{H}$ \\
\hline \multirow{2}{*}{$\begin{array}{l}\text { Number of Primary } \\
\text { Branches/Plant }\end{array}$} & $\begin{array}{c}\text { 285-1-3A-1-17-1 x } \\
\text { VRO-106 }\end{array}$ & $29.41^{* *}$ & -58.82 to 29.41 & $0.93^{* *}(4.40)$ & $\mathrm{L} \times \mathrm{H}$ \\
\hline & VRO-104 × VRO-106 & $22.22^{* *}$ & & $0.66^{* *}(4.40)$ & $\mathrm{H} \times \mathrm{H}$ \\
\hline \multirow{2}{*}{ Fruit Length $(\mathrm{cm})$} & $\begin{array}{c}285-1-3 A-1-17-1 \times 299- \\
52-5-6-5-8\end{array}$ & $19.17^{* *}$ & -39.77 to 19.17 & $0.96^{* *}(9.82)$ & $\mathrm{L} \times \mathrm{H}$ \\
\hline & $\begin{array}{c}285-1-3-1-15-2-1 \times \\
\text { VRO-178 }\end{array}$ & $17.04^{* *}$ & & $1.76^{* *}(10.44)$ & $\mathrm{L} \times \mathrm{H}$ \\
\hline \multirow{2}{*}{$\begin{array}{l}\text { Number of Fruits/ } \\
\text { Plant }\end{array}$} & $\begin{array}{c}285-1-5-1-16-23 \times \\
\text { VRO-178 }\end{array}$ & $89.70^{* *}$ & -45.26 to 89.70 & $5.74^{* *}(18.72)$ & $\mathrm{L} \times \mathrm{H}$ \\
\hline & VRO-178 × VRO-106 & $63.02^{* *}$ & & $2.77^{* *}(16.09)$ & $\mathrm{H} \times \mathrm{L}$ \\
\hline \multirow{2}{*}{$\begin{array}{l}\text { Days to } \mathbf{1}^{\text {st }} \text { Initiation } \\
\text { of ELCV }\end{array}$} & $\begin{array}{c}285-1-5-1-16-23 \times \\
\text { VRO-178 }\end{array}$ & $13.24^{* *}$ & -28.12 to 13.24 & $8.00^{* *}(45.67)$ & $\mathrm{L} \times \mathrm{H}$ \\
\hline & $\begin{array}{c}285-1-3-1-15-2-1 \times \\
\text { VRO-178 }\end{array}$ & $10.76^{* *}$ & & $3.90 * *(44.67)$ & $\mathrm{H} \times \mathrm{H}$ \\
\hline \multirow{2}{*}{$\begin{array}{l}\text { Node at } \mathbf{1}^{\text {st }} \text { Initiation } \\
\text { of ELCV }\end{array}$} & $\begin{array}{l}\text { VRO-104 × 299-52-5- } \\
6-5-8\end{array}$ & $20.00^{* *}$ & -40.00 to 20.00 & $0.02(6.00)$ & $\mathrm{L} \times \mathrm{L}$ \\
\hline & VRO-104 × BCO-1 & $20.00^{* *}$ & & $1.62^{* *}(6.00)$ & $\mathrm{L} \times \mathrm{L}$ \\
\hline \multirow{2}{*}{ PDI of ELCV (\%) } & $\begin{array}{c}285-1-5-1-16-23 \times \\
\text { VRO-178 }\end{array}$ & $-19.78^{* *}$ & 172.39 to -19.78 & $-12.14^{* *}(11.80)$ & $\mathrm{L} \times \mathrm{H}$ \\
\hline & $\begin{array}{c}285-1-3-1-15-2-1 \times \\
299-52-5-6-5-8\end{array}$ & $-15.11^{* *}$ & & $-2.57^{* *}(28.49)$ & $\mathrm{H} \times \mathrm{L}$ \\
\hline \multirow{3}{*}{ Fruit Yield/Plant (g) } & $\begin{array}{c}285-1-5-1-16-23 \times \\
\text { VRO-178 }\end{array}$ & $45.30^{* *}$ & -42.98 to 45.30 & $61.93^{* *}(230.15)$ & $\mathrm{L} \times \mathrm{H}$ \\
\hline & $\begin{array}{c}285-1-3-1-15-2-1 \times \\
\text { VRO-178 }\end{array}$ & $41.12^{* *}$ & & $19.48^{* *}(223.53)$ & $\mathrm{H} \times \mathrm{H}$ \\
\hline & $\begin{array}{c}285-1-3 A-1-17-1 \times \\
\text { VRO-178 }\end{array}$ & $36.26^{* *}$ & & $11.50^{* *}(227.97)$ & $\mathrm{H} \times \mathrm{H}$ \\
\hline
\end{tabular}

* and **: significant at $\mathrm{P}<0.05$ and $\mathrm{P}<0.01$, respectively; a Figures in parentheses indicate per se (mean) performance. bL= Non-significant gca effect; $\mathrm{H}=$ Significant gca effect in desired direction. 
Specific combining ability effects represent dominance and epistatic components of genetic variations which are not fixable but the crosses with high SCA effects involving good general combiner parents can be exploited in future breeding programme. The SCA effects for hybrids pertaining to thirteen characters are given in Table 5. Significant SCA effects in desired direction were recorded in seventeen crosses for fruit yield/plant; twelve crosses for PDI of ELCV; nine crosses for crosses for days to $1^{\text {st }}$ initiation of ELCV disease, seven crosses for node at 1st initiation of ELCV disease; eight crosses each for plant height and node at $1^{\text {st }}$ flowering; nine crosses for fruit weight, fourteen crosses for number of fruits/plants, thirteen crosses for fruit length, ten crosses for number of primary branches/plants, six crosses each for days to $50 \%$ flowering and days to $1^{\text {st }}$ flowering. However, none of the hybrids showed significant positive SCA effects for fruit diameter.

The cross 285-1-5-1-16-23 $\times$ VRO-178 exhibited the maximum significant SCA effects in desired direction for fruit yield/plant along with PDI of ELCV, days to $1^{\text {st }}$ initiation of ELCV disease, node at $1^{\text {st }}$ initiation of ELCV disease, number of fruits/plant, and fruit length having one of the parents as good general combiner for fruit yield/plant with other desirable horticultural traits, indicating that this hybrid is expected to produce segregates with high yield, and better tolerance to ELCV disease of fixable nature in segregating generations through simple pedigree method. Moreover, significant SCA effects in desired direction for fruit yield/plant, number of fruits/plant, and PDI of ELCV, and days to $1^{\text {st }}$ initiation of ELCV disease were shown by three crosses 285-13A-1-17-1 × BCO-1, VRO-104 × VR0-178 and 285-1-3-1-15-2-1 × VRO-106 which also involved one of the parents as good general combiner for fruit yield/plant and other desirable horticultural traits, suggesting further exploitation of these crosses in segregation generation to identify superior lines. The highest per se performance for fruit yield/plant along with number of fruits/ plants, and minimum severity of ELCV disease was recorded in cross 285-1-5-1-16-23 × VRO-178 followed by the cross VRO-104 $\times$ VRO-178 (Table 5).

From the foregoing observations, it appeared that different cross combinations exhibited different SCA effects and only a few crosses showed consistently either positive or negative SCA effects for certain characters. Based on SCA effects and per se performance two cross combinations namely, 285-1-5-1-16-23 $\times$ VRO-178 and VRO-104 $\times$ VRO-178 could be identified as good specific combiners for future use in breeding programme of okra. Significant SCA effects in desired direction for all the economic traits of okra involving various combinations of GCA effects of the parents were reported by earlier workers [28], for plant height; Kayande et al. [29], for number of branches/plant; Rewale et al. [30], for number of fruits/plant; Das et al. [13], and Kayande et al. [29], for days to $1^{\text {st }}$ flowering, fruit length, fruit diameter, fruit weight and fruit yield/plant].

The perusal of different heterotic cross combinations based on GCA effects of the parents revealed that the crosses involved four types of combinations namely, $\mathrm{H} \times \mathrm{H}, \mathrm{H} \times \mathrm{L}, \mathrm{L} \times \mathrm{H}$ and $\mathrm{L} \times \mathrm{L}$, where $\mathrm{H}$ stands for significant GCA effect in desired direction and $\mathrm{L}$ for non-significant GCA effect of the parent (Table 5). In the $\mathrm{H} \times$ $\mathrm{H}$ type cross combinations, additive as well as additive $\times$ additive type of interactions was involved. These crosses would be very useful as desirable segregates would be fixed in early advance generation. On the other hand, crosses of $\mathrm{H} \times \mathrm{L}$ type or $\mathrm{L} \times \mathrm{H}$ type involved at least one parent with significant GCA effect which indicated that predominantly additive effect was present in good combiner and possibly complementary epistatic effect in poor combiner and these two gene actions acted in complementary fashion to maximize the expression as suggested by Salimath and Bahl [31]. In crosses involving $\mathrm{L} \times \mathrm{L}$ category, sca effects seemed to have played a very important role and high performance was due to non-additive gene action [11].

Table 6: Per cent infection of ELCV disease in Tolerant and Susceptible hybrids after cross inoculation.

\begin{tabular}{|c|c|c|c|c|c|c|c|}
\hline Crosses & $\begin{array}{c}\text { Number of } \\
\text { Plants Inoc- } \\
\text { ulated with } \\
\text { Whiteflies }\end{array}$ & $\begin{array}{c}\text { Plants } \\
\text { Infected at } \\
\text { 30 days after } \\
\text { Inoculation }\end{array}$ & $\begin{array}{c}\text { Plants In- } \\
\text { fected at 45 } \\
\text { Days after } \\
\text { Inoculation }\end{array}$ & $\begin{array}{c}\text { Plants Infect- } \\
\text { ed at 60 Days } \\
\text { after Inocula- } \\
\text { tion }\end{array}$ & $\begin{array}{c}\text { Plants Infect- } \\
\text { ed at 75 Days } \\
\text { after Inocula- } \\
\text { tion }\end{array}$ & $\begin{array}{c}\text { Plants } \\
\text { Infected at } \\
\text { 90 Days after } \\
\text { Inoculation }\end{array}$ & $\begin{array}{c}\text { Percentage of Plants } \\
\text { Infected at 90 Days } \\
\text { after Inoculation }\end{array}$ \\
\hline $\begin{array}{c}285-1-5-1-16-23 \times \\
\text { VRO-178 (Tolerant } \\
\text { cross) }\end{array}$ & 20 & 0 & 0 & 0 & 1 & 3 & 15 \\
\hline $\begin{array}{c}285-1-3-1-15-2-1 \times \\
\text { VR0-178 (Tolerant } \\
\text { cross) }\end{array}$ & 20 & 0 & 0 & 1 & 3 & 4 & 20 \\
\hline $\begin{array}{c}\text { BCO-1 } \text { VRO-106 } \\
\text { (Susceptible cross) }\end{array}$ & 20 & 5 & 8 & 14 & 16 & & 18 \\
\hline
\end{tabular}

The estimates of heterosis, relative to better parental values were presented in Table 5. No hybrid exhibited significant heterobeltiosis in desired direction for days to $1^{\text {st }}$ flowering, fruit diameter and fruit weight. The extent of heterobeltiosis varied from $27.03 \%$ to $-6.47 \%$ for days to 1 st flowering; $50.00 \%$ to $-41.41 \%$ for node at $1^{\text {st }}$ flowering; $-58.82 \%$ to $29.41 \%$ for number of primary branches/plants. -39.77 to $19.17 \%$ for fruit length; $-17.98 \%$ to

$5.00 \%$ for fruit diameter; $-45.26 \%$ to $89.70 \%$ for number of fruits/ plant; $-44.51 \%$ to $9.84 \%$ for fruit weight; $-28.12 \%$ to $13.24 \%$ for days to $1^{\text {st }}$ initiation of ELCV disease; $-40.00 \%$ to $20.00 \%$ for node at $1^{\text {st }}$ initiation of ELCV disease; $172.39 \%$ to $-19.78 \%$ for PDI of ELCV and $-37.44 \%$ to $45.30 \%$ for fruit yield/plant. The maximum positive heterosis over better-parent for fruit yield/plant was exhibited by 285-1-5-1-16-23 × VRO-178 (45.30\%**) followed by 
285-1-3-1-15-2-1 × VRO-178 (41.12\%**) and 285-1-3A-1-17-1 × VRO-178 (36.26\%**). Two most promising hybrids (285-1-5-116-23 $\times$ VRO-178 and 285-1-3-1-15-2-1 × VRO-178) along with one most susceptible hybrid (BCO-1 $\times$ VRO-106) were grown under artificial inoculation condition to confirm the tolerance against this virus. Out of twenty plants inoculated with whiteflies, none of the plants of the hybrid (285-1-5-1-16-23 × VRO-178) was developed any symptom of ELCV disease even after 60 days of inoculation and grow normally even after feeding by the vectors. Only three plants after 90 days of inoculation showed $15.00 \%$ disease incidence in 285-1-5-1-16-23 $\times$ VRO-178 as compared to another promising hybrid 285-1-3-1-15-2-1 $\times$ VRO-178 which showed $20.00 \%$ disease incidence. However, the susceptible hybrid BCO-1 × VRO-106 exhibited 90.00\% disease incidence after 90 days of inoculation (Table 6).

On the basis of per se performance, the hybrid 285-1-3A-1-17$1 \times$ VR0-178 exhibited the maximum fruit yield/plant $(227.97 \mathrm{~g} /$ plant) and low ELCV disease severity ( $11.62 \%$ ) and the top parent was 285-1-3A-1-17-1 (167.30g/plant yield; $11.70 \%$ PDI) which involved 285-1-3A-1-17-1 as one of the parents indicated the involvement of additive gene action for the control of this character. The observation on the extent of heterobeltiosis for these characters was reported by many workers [14,32]. It was found that closely or distantly related parents exhibited low heterosis, but crosses between parents of intermediate divergence classes tended to show higher heterosis for fruit yield and other important traits.

The values of dominance estimates (Potence ratio) illustrated in $28 \mathrm{~F}_{1}$ crosses are presented in Table 7 . In case of days to $1^{\text {st }}$ flowering, they were more than \pm 1 for fourteen crosses, between \pm 1 in thirteen crosses and +1 in one hybrid, indicating over-dominance, partial dominance and complete dominance, respectively for the inheritance of this trait. Days to $50 \%$ flowering showed that they were more than \pm 1 for seventeen hybrids, between \pm 1 in ten crosses, and 0 in one hybrid indicating over-dominance, partial dominance, and absence of dominance, respectively. Node at first flowering expressed over-dominance in seventeen crosses, partial dominance in nine crosses, and absence of dominance in one cross. Plant height showed that potence ratios ranged from -10.94 to 80.80 , and they were more than +1 for sixteen crosses, and between \pm 1 in twelve crosses indicating over-dominance and partial dominance, respectively towards the higher plant height. Dominance estimates of number of primary branches/plants revealed that they were more than +1 in fifteen crosses, between \pm 1 in eight crosses, +1 in three crosses and 0 in two crosses indicating over-dominance, partial dominance and absence of dominance, respectively. In case of fruit length, eighteen hybrids exhibited over-dominance and ten hybrids showed partial dominance. Potence ratio of fruit diameter expressed overdominance in fifteen crosses, partial dominance in eleven hybrids and absence of dominance in two hybrids. Regarding fruit weight, twelve crosses exhibited over-dominance and sixteen crosses showed partial dominance. Number of fruits/plants exhibited over dominance in nineteen crosses and partial dominance in nine hybrids in the inheritance of this trait. Days to $1^{\text {st }}$ initiation of ELCV disease showed over dominance in eleven crosses and partial dominance in seventeen crosses. In case of node at $1^{\text {st }}$ initiation of ELCV disease, six hybrids exhibited over-dominance, nine hybrids showed partial dominance and nine crosses expressed complete dominance and four crosses exhibited no dominance. PDI of ELCV showed that potence ratios ranged from -2.53 to 20.83 , and they were more than +1 for fourteen crosses, between \pm 1 in thirteen crosses and 0 in single cross indicating over-dominance, partial dominance and no dominance, respectively towards better tolerance of ELCV disease. In respect to fruit yield/plant, potence ratios ranged from -23.58 to 14.63 , and they were more than +1 for twenty-three crosses indicating over-dominance, between \pm 1 in four crosses, indicating partial dominance and +1 in single cross, indicating complete dominance towards the higher fruit yield.

Table 7: Estimates of dominance effects of thirteen characters of okra.

\begin{tabular}{|c|c|c|c|c|c|c|c|c|c|c|c|c|c|}
\hline $\begin{array}{l}\text { Cross combina- } \\
\text { tions }\end{array}$ & $\begin{array}{l}\text { Days to } \\
1^{\text {st }} \text { Flow- } \\
\text { ering }\end{array}$ & $\begin{array}{l}\text { Days } \\
\text { to } 50 \% \\
\text { Flower- } \\
\text { ing }\end{array}$ & $\begin{array}{l}\text { Node } \\
\text { at } 1^{\text {st }} \\
\text { flower- } \\
\text { ing }\end{array}$ & $\begin{array}{l}\text { Plant } \\
\text { Height } \\
\text { (cm) }\end{array}$ & $\begin{array}{l}\text { Num- } \\
\text { ber of } \\
\text { Primary } \\
\text { Branch- } \\
\text { es/Plant }\end{array}$ & $\begin{array}{l}\text { Fruit } \\
\text { Length } \\
\text { (cm) }\end{array}$ & $\begin{array}{l}\text { Fruit } \\
\text { Diam- } \\
\text { eter } \\
(\mathrm{cm})\end{array}$ & $\begin{array}{c}\text { Num- } \\
\text { ber of } \\
\text { Fruits/ } \\
\text { Plant }\end{array}$ & $\begin{array}{l}\text { Fruit } \\
\text { Weight } \\
\text { (g) }\end{array}$ & $\begin{array}{l}\text { Days to } \\
1^{\text {st }} \text { Initi- } \\
\text { ation of } \\
\text { ELCV }\end{array}$ & $\begin{array}{c}\text { Node at } \\
1^{\text {st }} \text { Initi- } \\
\text { ation of } \\
\text { ELCV }\end{array}$ & $\begin{array}{l}\text { PDI } \\
\text { of } \\
\text { ELCV }\end{array}$ & $\begin{array}{c}\text { Fruit } \\
\text { Yield/ } \\
\text { Plant } \\
\text { (g) }\end{array}$ \\
\hline $\begin{array}{c}\text { 285-1-3A-1-17-1 } \\
\times \text { VRO-104 }\end{array}$ & 4.33 & 3.67 & 5 & -10.94 & -2.4 & 4.31 & 0.75 & 1.45 & 0.57 & -1.06 & 0 & 0.19 & 1.06 \\
\hline $\begin{array}{c}285-1-3 A-1-17-1 \\
\times 285-1-5-1-16- \\
23\end{array}$ & 4.33 & 3.67 & -0.5 & -3.58 & -3 & -4.25 & -11 & 1.52 & -44 & -0.71 & 0.2 & 0.17 & 0.57 \\
\hline $\begin{array}{c}285-1-3 A-1-17-1 \\
\times 285-1-3-1-15- \\
2-1\end{array}$ & 0.17 & -0.5 & 6.88 & -0.28 & -5 & 5 & -1.29 & 1.18 & 1.48 & -2.05 & -1 & 0.29 & 2.93 \\
\hline $\begin{array}{c}285-1-3 A-1-17-1 \\
\times \text { VRO-178 }\end{array}$ & -2.11 & -7 & 0 & -2.22 & 0 & 1.24 & -1.8 & 3.4 & -0.9 & 4.42 & 1 & -1.05 & 14.63 \\
\hline $\begin{array}{l}285-1-3 A-1-17-1 \\
\times 299-52-5-6-5-8\end{array}$ & -2 & -4.34 & -1.75 & -0.62 & 0.44 & 20.75 & 1.75 & 20.27 & 1.81 & 1.17 & 1 & -0.89 & 2.82 \\
\hline
\end{tabular}




\section{Agricultural Research \& Technology: Open Access Journal}

\begin{tabular}{|c|c|c|c|c|c|c|c|c|c|c|c|c|c|}
\hline $\begin{array}{c}\text { 285-1-3A-1-17-1 } \\
\times \text { VRO-106 }\end{array}$ & -0.25 & -0.71 & -1.75 & 1.87 & 11 & -0.87 & -3.33 & 1.46 & -1.85 & -0.74 & -0.5 & 0.2 & 1.17 \\
\hline $\begin{array}{c}\text { VRO-104 × 285-1- } \\
5-1-16-23 \\
\end{array}$ & -1 & 1.67 & -1 & -1.85 & 0.5 & 7.73 & 0.8 & 1.79 & -0.6 & -0.56 & 1 & -2.16 & 2.72 \\
\hline $\begin{array}{c}\text { VRO- } 104 \times 285-1- \\
3-1-15-2-1\end{array}$ & 0.71 & 0.24 & 5.06 & 0.44 & 3 & -6.83 & 0.07 & -0.38 & 0.66 & 0.83 & 1 & 0.01 & 0.72 \\
\hline $\begin{array}{c}\text { VRO-104 × VRO- } \\
178\end{array}$ & 0.71 & 8 & 0.2 & -1.65 & -8.38 & -46.6 & -2.33 & 8.75 & -0.44 & 1.54 & 1.67 & -1.04 & 3.06 \\
\hline $\begin{array}{c}\text { VRO-104 × } 299- \\
52-5-6-5-8\end{array}$ & 9 & 3 & -1 & -0.64 & -0.71 & 4.08 & -2.33 & 0.7 & 0.18 & 0.4 & 1.67 & 0.27 & 2.26 \\
\hline VRO-104 × BCO-1 & 0.67 & 0.5 & -0.34 & -1.95 & -0.71 & 0.67 & 0.4 & -0.96 & -0.32 & 0.5 & 2 & 2.1 & -23.58 \\
\hline $\begin{array}{c}\text { VRO-104 × VRO- } \\
106\end{array}$ & -0.82 & -1 & -1 & 0.11 & 9 & 0.05 & -1.29 & -1.41 & -0.11 & -2.03 & 2 & 10.57 & -9.18 \\
\hline $\begin{array}{c}285-1-5-1-16-23 \\
\times 285-1-3-1-15- \\
2-1\end{array}$ & -1 & -1.5 & -0.38 & 1.12 & 1 & 1.51 & -0.2 & 1.18 & 2.48 & -0.43 & 1 & -1.32 & 1.54 \\
\hline $\begin{array}{c}285-1-5-1-16-23 \\
\times \text { VRO-178 }\end{array}$ & -2.55 & 3 & -0.38 & -0.12 & -0.5 & 8.67 & -1.86 & 10.03 & -0.9 & 1.92 & 1.5 & -1.18 & 3.29 \\
\hline $\begin{array}{r}285-1-5-1-16-23 \\
\times 299-52-5-6-5-8 \\
\end{array}$ & -3 & -7 & -6.97 & -0.03 & 0.33 & 0.54 & 0.8 & -0.01 & 1.6 & 0.05 & 3 & -0.55 & 1.88 \\
\hline $\begin{array}{c}285-1-5-1-16-23 \\
\times \text { BCO-1 }\end{array}$ & -2.33 & -1 & -1.5 & -3.69 & 1 & -0.25 & 0.8 & -8.9 & 0.56 & -0.71 & -1 & 20.83 & -4.19 \\
\hline $\begin{array}{c}285-1-5-1-16-23 \\
\times \text { VRO-106 }\end{array}$ & -1.5 & -1.29 & -1.5 & 1.25 & 2.33 & -2.46 & -5 & -3.8 & -1.29 & 0.45 & -1 & 3.45 & -2.25 \\
\hline $\begin{array}{c}\text { 285-1-3-1-15-2-1 } \\
\times \text { VRO-178 }\end{array}$ & -1.29 & -2.6 & -0.84 & 0.32 & 3.67 & 6.24 & 0 & 8.55 & 0.11 & 2.86 & 1 & -1.2 & 10.94 \\
\hline $\begin{array}{l}285-1-3-1-15-2-1 \\
\times 299-52-5-6-5-8 \\
\end{array}$ & 2.33 & 3 & -1.44 & -1.47 & -2.5 & 9.46 & 0.6 & 0.46 & 1.58 & 3.99 & 1 & -2.53 & 5.06 \\
\hline $\begin{array}{c}285-1-3-1-15-2-1 \\
\times \text { BCO-1 }\end{array}$ & -1 & -0.33 & 6.88 & 1.15 & -2.33 & -0.27 & -2.6 & 0.76 & -0.59 & -0.36 & -0.33 & -1.1 & 1 \\
\hline $\begin{array}{c}\text { 285-1-3-1-15-2-1 } \\
\times \text { VRO-106 }\end{array}$ & -1 & -2.33 & 6.88 & 0.02 & -1 & -2.92 & -19 & 2.36 & 1.83 & 0.4 & -1 & -1.92 & 3.57 \\
\hline $\begin{array}{c}\text { VRO- } 178 \times 299- \\
52-5-6-5-8\end{array}$ & 1 & -2.33 & -6.46 & 0.94 & -0.14 & 2.71 & 3.67 & 2.24 & -0.1 & 1.25 & 1 & -1 & 3.25 \\
\hline VRO-178 × BCO-1 & -1.22 & -3 & -1.5 & 1.11 & -3.35 & 0.38 & 0.43 & 1.2 & -33 & -0.29 & 0.2 & 0.11 & 0.41 \\
\hline $\begin{array}{c}\text { VRO- } 178 \times \text { VRO- } \\
106 \\
\end{array}$ & -1.18 & -0.75 & -1.67 & 80.8 & 5 & -1.18 & -1.55 & 12.31 & -2.64 & -0.33 & 1 & -0.74 & 2.92 \\
\hline $\begin{array}{c}299-52-5-6-5-8 \times \\
\text { BCO-1 }\end{array}$ & -1 & 0 & -1.75 & -0.84 & -1.29 & 0.64 & 0.8 & -0.53 & 0.39 & -0.23 & 0 & 0.38 & 0.14 \\
\hline $\begin{array}{c}299-52-5-6-5-8 \times \\
\text { VRO-106 }\end{array}$ & -0.2 & -0.5 & -1.5 & -0.98 & -2.33 & -0.88 & -0.86 & 1.32 & -0.78 & -2.5 & 0 & -0.08 & 7.9 \\
\hline BCO-1 × VRO-106 & -0.6 & -1 & -1.5 & 3.89 & 1 & -11.9 & -6.5 & 0.76 & -5.76 & -0.78 & -1 & 2.99 & -12.33 \\
\hline
\end{tabular}

The above results reflected various degrees of dominance; i.e. complete, partial- to dominance, over-dominance or absence of dominance which involved in the inheritance of characters studied. However, the role of over-dominance and partialdominance for most of the crosses in the inheritance of these traits was recorded. The present study was in accordance with Sharma and Mahajan [33]; El-Maksoud et al. [34], who reported that fruit weight was under the influence of over dominance to partialdominance action. Seth et al. [14], observed preponderance of partial- dominance in most of hybrids in days to $50 \%$ flowering and fruit diameter. They also recorded overwhelming response of over dominance in majority of the hybrids in conditioning of characters like node at first flowering, fruit length, number of fruits/plants, and fruit yield/plant. No previous studies to the best our knowledge was documented so far in okra to support our findings regarding disease severity traits of ELCV.

\section{Conclusion}

The results suggested that okra breeding programs for ELCV disease tolerance should use the strategy of selecting parents and hybrids tolerant to ELCV disease based on estimates of GCA and SCA for ELCV disease severity under field condition. The breeding strategies for the improvement of studied traits controlled by different gene effects are discussed. Among the parents, 285-13A-1-17-1 and VRO-178 were found to be the most promising combiners for fruit yield along with ELCV disease severity traits, 
and they could be used further in okra hybridization programmes. The crosses 285-1-5-1-16-23 × VRO-178 and 285-1-3-1-15-2-1 $\times$ VRO-178 ranked top in respect of yield, and level of tolerance under field and epiphytotic conditions against enation leaf curl virus disease and found promising for commercial exploitation after its critical evaluation. The present findings also suggested that all the characters under study could not be evaluated with equal efficiencies by a single parent or hybrid. Partial- to overdominance reactions for the inheritance of fruit yield and other economic important traits have been realized.

\section{References}

1. Hazra P, Chattopadhyay A, Karmakar K, Dutta S (2011) Modern Technology in Vegetable Production. New India Publishing Agency, New Delhi, India.

2. Hughes J (2009) Just famine foods? What contribution can underutilized plant make to food security? Acta Horticulturae 806: 39-47.

3. Das S, Chattopadhyay A, Chattopadhyay SB, Dutta S, Hazra P (2012) Genetic parameters and path analysis of yield and its components in okra at different sowing dates in the Gangetic plains of eastern India. African Journal of Biotechnology 11(95): 16132-16141.

4. Yadav Y, Maurya PK, Devi AP, Jamir I, Bhattacharjee T, et al. (2018a) Enation leaf curl virus (ELCV): A real threat in major okra production belts of India: a review. Journal of Pharmacognosy and Phytochemistry $7(2): 3795-3802$.

5. Chandran SA, Packialakshmi RM, Subhalakshmi K, Prakash C, Poovannan K (2013) First report of an alphasatellite associated with okra enation leaf curl virus. Virus Genes 46(3): 585-587.

6. Venkataravanappa V, Reddy CNL, Jalali S, Briddon RW, Reddy MK (2015) Molecular identification and biological characterisation of a begomovirus associated with okra enation leaf curl disease in India. Europran Journal of Plant Patholology 141(2): 217-235.

7. Yadav Y, Maurya PK, Banerjee S, Bhattacharjee T, Jamir I, et al. (2018b) Selecting donor parents for future breeding aiming at tolerance to viral diseases with special emphasis on enation leaf curl virus in okra. International Journal of Vegetable Science.

8. Singh SJ (1996) Assessment of losses in okra due to enation leaf curl virus. Indian Journal of Virology 12(1): 51-52.

9. Singh B, Rai M, Kalloo G, Satpathy S, Pandey KK (2007) Wild taxa of okra (Abelmoschus species): reservoir of genes for resistance to biotic stresses. Acta Horticulturae 752: 323-328.

10. Sanwal SK, Singh M, Singh B, Naik PS (2014) Resistance to yellow vein mosaic virus and okra enation leaf curl virus: challenges and future strategies. Current Science 106: 470-471.

11. Bhutia ND, Seth T, Shende VD, Dutta S, Chattopadhyay A (2015) Estimation of heterosis, dominance effect and genetic control of fresh fruit yield, quality and leaf curl disease severity traits of chilli pepper (Capsicum annuum L.). Scientia Horticulturae 182(23): 47-55.

12. Sprague GF, Tatum LA (1942) General versus specific combining ability in single crosses of corn. Journal of the American Society of Agronomy 3: $923-942$.

13. Das S, Chattopadhyay A, Dutta S, Chattopadhyay SB, Hazra P (2013) Breeding okra for higher productivity and yellow vein mosaic tolerance. International Journal of Vegetable Science 19(1): 58-77.

14. Seth T, Chattopadhyay A, Dutta S, Hazra P, Singh B (2016) Evidence of economic heterosis and genetic control of fruit yield and yellow vein mosaic virus disease severity traits of okra. Vegetos 29(3): 3 .
15. Griffing B (1956) Concept of general and specific combining ability in relation to diallel system. Australian Journal of Biological Sciences 9: 463-493.

16. Chattopadhyay A, Dutta S, Bhattacharya I, Karmakar K, Hazra P (2007) Technology for Vegetable Crop Production. All India Coordinated Research Project on Vegetable Crops. Directorate of Research, West Bengal, India.

17. Alegbejo MD (1997) Evaluation of okra genotype for resistance to okra mosaic virus. Proceedings of the 15th Annual conference of the Horticultural Society of Nigeria, held at the National Horticultural Research Institute, Ibadan, pp. 60.

18. Nariani TK, Seth MN (1958) Reaction of Abelmoschus and Hibiscus species to yellow vein mosaic virus. Indian Phytopathology 11: 137143.

19. Singh RF, Chaudhary BD (1985) Biometrical Methods in Quantitative Genetic Analysis. Kalyani Publishers, New Delhi, India, pp. 302.

20. Hayes HK, Immer FR, Smith DE (1955) Methods of Plant Breeding. McGraw Hill Book Co., New York, USA, pp. 551.

21. Smith HH (1952) Fixing transgressive vigour in Nicotiana rustica. In: Gowen JW (Eds.), Heterosis. Iowa State College Press, Ames, IA, USA, pp. 161-174.

22. Baker RJ (1978) Issues in diallel analysis. Crop Science 18(4): 533-536.

23. Jensen NF (1970) A diallel selective mating system for cereal breeding. Crop Science 10(6): 629-635.

24. Redden RJ, Jensen NF (1974) Mass selection and mating system in cereals. Crop Science 14(3): 345- 350.

25. Shende VD, Seth T, Mukherjee S, Chattopadhyay A (2012) Breeding tomato (Solanum lycopersicum) for higher productivity and better processing qualities. SABRAO Journal of Breeding and Genetics 44(2): 302-321.

26. Jindal SK, Arora D, Ghai TR (2009) Heterobeltiosis and combining ability for earliness in okra [Abelmoschus esculentus (L.) Moench]. Crop Improvement 36(2): 59-66.

27. Kumar A, Baranwal DK, Aparna J, Srivastava K (2013) Combining ability and heterosis for yield and its contributing characters in okra [Abelmoschus esculentus (L.) Moench]. Madras Agricultural Journal 100(1-3): 30-35.

28. Thippeswamy S (2001) Line $\times$ Tester analysis for heterosis and combining ability using male sterile lines in okra. M.Sc. (Ag.) Thesis, University of Agricultural Sciences, Dharwad, India, pp. 153.

29. Kayande NV, Kumbhalkar HB, Shinde S (2018) Selection of parents based on combining ability studies in okra [Abelmoschus esculentus (L.) Moench]. Int J Curr Microbiol App Sci 6: 1935-1940.

30. Rewale VS, Bendale VW, Bhave SG, Madav RR, Jadhav BB (2003) Combining ability of yield and yield components in okra. Journal of Maharashtra Agricultural University 28: 244-246.

31. Salimath PM, Bahl PN (1985) Heterosis and Combining ability for earliness in chickpea (Cicer arietinum L.). Indian Journal of Genetics and Plant Breeding 45(1): 97-100.

32. Makdoomi MI, Kouser PW, Dar ZA, Hussain K, Nabi A, et al. (2018) Heterosis studies in okra (Abelmoschus esculentus L. Moench). Int J Curr Microbiol App Sci 7(2): 3297-3304.

33. Sharma BR, Mahajan YP (1978) Line $\times$ Tester analysis of combining ability and heterosis for some economic characters in okra. Scientia Horticulturae 9(2): 111-118.

34. El-Maksoud MA, Helal RM, Mohamed MH (1984) Heritability estimates and correlation studies of six economic characters in okra. Annals of Agriculture 29(1): 439-452. 


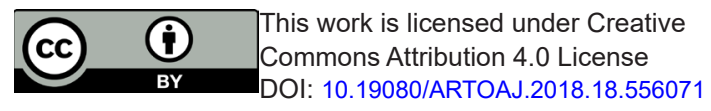

Your next submission with Juniper Publishers
will reach you the below assets
- Quality Editorial service
- Swift Peer Review
- Reprints availability
- E-prints Service
- Manuscript Podcast for convenient understanding
- Global attainment for your research
- Manuscript accessibility in different formats
( Pdf, E-pub, Full Text, Audio)
- Unceasing customer service
Track the below URL for one-step submission
https://juniperpublishers.com/online-submission.php

